\title{
FRAN: PAMETEN IN INTUITIVEN?
}

\section{Iztok KOSEM}

Filozofska fakulteta, Univerza v Ljubljani; Trojina, zavod za uporabno slovenistiko

Kosem, I. (2014): Fran: pameten in intuitiven? Slovenščina 2.o, 2 (2): 161-193.

URL: http://www.trojina.org/slovenscina2.o/arhiv/2014/2/Slo2.o_2014_2_o9.pdf.

Slovarji so uporabnikom pogosto ponujeni (tudi) prek slovarskih portalov, ki združujejo različne slovarje in pogosto tudi ostale referenčne vire. Portali so odgovor na potrebe sodobnega slovarskega uporabnika, ki je vajen hkratnega dostopa do različnih vrst informacij na enem mestu. Slovarski portali so že nekaj časa prisotni tudi $\mathrm{v}$ slovenskem prostoru, vendar pa se je šele nedavno vzpostavljeni portal Fran Inštituta za slovenski jezik Frana Ramovša ZRC SAZU prvi osredotočil samo na (sicer lastne) enojezične slovarske vire in tako povzročil pomemben premik $\mathrm{v}$ rabi enojezičnih slovarjev pri nas. $\mathrm{V}$ prispevku najprej pregledamo nekatere tuje in slovenske slovarske portale, nato pa se osredotočimo na pregled ter evalvacijo portala Fran. Preverili smo način predstavljanja slovarskih informacij z vidika preglednosti in jasnosti, preizkusili različne možnosti iskanj ter ocenili funkcionalnosti portala in pomoč uporabnikom. Evalvacijo smo opravili tudi z vidika dognanj študij slovarskih uporabnikov. V zaključku prispevka povzamemo glavne ugotovitve in podamo razmisleke o pomenu portala za prihodnost slovenske leksikografije.

Ključne besede: slovarski portal, slovarji, leksikografija, uporabniška prijaznost, vmesnik

\section{UVOD}

Tehnološki napredek zadnjih desetletij je prinesel nove oblike medijev, s katerimi je slovarska vsebina posredovana uporabniku. Prvi elektronski mediji (npr. zgoščenke) so bili zgolj dodatki tiskanim različicam slovarjev, prihod in uveljavitev spletnega medija pa sta $\mathrm{v}$ leksikografijo vnesla pomembne spremembe, saj se je začel spreminjati način predstavljanja (in konceptualiziranja) slovarske vsebine (dobre primere najdemo že v tej tematski 
številki, gl. zlasti prispevke M. Rundella, J. Simpsona, P. Žmigrodzkega, B. Arias-Badie idr. in P. Gantar). To je bila tudi posledica dejstva, da se je izoblikoval nov profil slovarskega uporabnika, ki preko spleta dostopa ne samo do slovarskih, ampak tudi do vseh drugih informacij in storitev. Lastnost spletnega medija, da lahko ponudi dostop do skorajda neomejenih količin informacij, je izdelovalcem slovarjev ponudila možnost, da so na t. i. slovarskih portalih uporabnikom ponudili hkraten dostop do več slovarjev in drugih referenčnih virov.

$\mathrm{V}$ prispevku se po pregledu nekaterih tujih in slovenskih slovarskih portalov osredotočamo na pregled in evalvacijo nedavno vzpostavljenega slovarskega portala Fran Inštituta za slovenski jezik Frana Ramovša ZRC SAZU, ki je zaradi svoje vsebine, pomembnosti ustanove, pod okriljem katere je nastal, ${ }^{1}$ pa tudi zaradi načina promocije vzbudil veliko zanimanja in usmeril pozornost javnosti na povezljiv način podajanja različnih slovarskih vsebin, $\mathrm{s}$ tem pa prevzel tudi odgovornost za uveljavljanje take rabe slovarjev v slovenskem prostoru. V prispevku bomo preverili Franov način predstavljanja slovarskih informacij z vidika preglednosti in jasnosti, preizkusili bomo različne možnosti iskanj ter ocenili funkcionalnosti portala in pomoč uporabnikom. V zaključku bomo povzeli glavne ugotovitve in podali razmisleke o njegovem pomenu za prihodnost slovenske leksikografije.

\section{SLOVARJI IN SLOVARSKI PORTALI}

Lew (2011) loči štiri vrste spletnih slovarskih virov: posamezne slovarje, slovarske zbirke (angl. 'dictionary sets'), slovarske portale (angl. 'dictionary portals') in slovarske agregatorje (angl. 'dictionary aggregators'). Prva skupina so spletne strani posameznih slovarjev, slovarske zbirke so različni slovarji istega založnika, ponujeni na eni spletni strani, slovarski portali so zgolj skupek povezav na posamezne slovarje različnih avtorjev oz. založnikov, slovarski

\footnotetext{
1 »Inštitut za slovenski jezik Frana Ramovša ZRC SAZU je nacionalno središče za sistematično spremljanje in razlago slovenskega jezikovnega gradiva (http://isjfr.zrc-sazu.si/).
} 
agregatorji pa prikažejo vse zadetke iz različnih slovarjev (različnih založb) na eni spletni strani.

Lewova kategorizacija je problematična, ker ne pokriva večslovarskega vira, ki je postal v leksikografiji zelo razširjen: spletne strani, ki na enem mestu ponuja hkratni dostop do informacij iz različnih tovrstnih jezikovnih virov. Prav način iskanja se zdi glavna razlikovalna lastnost virov z več slovarji. Zato predlagamo nekoliko prilagojeno kategorizacijo in dodajamo primere zanjo:

a) Slovarski portal. Gre za vir, ki nudi dostop do različnih enojezičnih ali večjezičnih slovarskih in drugih referenčnih virov (istega založnika) in hkratno iskanje po njih. Način iskanja in prikaz zadetkov je različen: nekateri portali pokažejo zadetke iz vseh ponujenih slovarjev hkrati (npr. K Dictionaries ${ }^{2}$ ), drugi portali pokažejo zadetke iz enega slovarja in uporabniku ponudijo dostop do sorodnega sestavka $\mathrm{v}$ drugem slovarju, bodisi prek povezave (npr. Oxford Dictionaries ${ }^{3}$ in Leo4) bodisi v obliki zavihka (npr. Collins Dictionaries5 in WordReference ${ }^{6}$ ). Nekateri portali, zlasti enojezični, ponujajo tudi vsebino enciklopedij (npr. Merriam-Webster7) in prikaz podatkov iz korpusov (npr. DWDS $\left.^{8}\right)$.

b) Slovarski agregator. Vir, ki na eni strani prikaže zadetke iz različnih slovarjev na spletu. Primera takšnega vira sta Dictionary.com ${ }^{9}$ in Wordnik ${ }^{10}$.

c) Zbirka slovarskih povezav. Vir ponudi povezave do slovarjev in kratko informacijo o njihovi vsebini. Dober primer takšnega vira je stran

\footnotetext{
2 http://kdictionaries-online.com

3 http://www.oxforddictionaries.com

4 https://dict.leo.org

5 http://www.collinsdictionary.com

6 http://www.wordreference.com

7 http://www.merriam-webster.com

8 http://www.dwds.de

9 http://dictionary.reference.com

10 http://www.wordnik.com
} 
Spletni slovarji ${ }^{11}$. Različica zbirke povezav je tudi OneLook, ${ }^{12}$ ki podobno kot agregatorji omogoča iskanje po številnih slovarjih, vendar pa se od njih razlikuje v tem, da zadetke ponudi v obliki povezav na slovarske sestavke na izvirnih spletnih straneh slovarjev.

V nadaljevanju se bomo osredotočili na večslovarske vire, velja pa na tem mestu izpostaviti, da tudi spletne strani posameznih slovarjev postajajo podobne portalom, saj pogosto ponujajo dostop tudi do drugih sorodnih virov istega založnika. Tako recimo Macmillan English Dictionary13 uporabniku poleg slovarskega sestavka pokaže tudi relevantno vsebino iz tezavra (Slika 1).14

\footnotetext{
11 http://www.evroterm.gov.si/slovar/

$12 \mathrm{http}: / /$ www.onelook.com

13 http://www.macmillandictionary.com

14 Do nedavnega je imel uporabnik slovarja možnost preklopa med iskanjem po slovarju in tezavru, pri čemer si je lahko med ogledovanjem gesel iz prvega vira ogledal vsebino iz drugega vira s klikom na povezavo. Zdaj so spremenili privzeto nastavitev in se vsebina obeh virov prikaže avtomatično, uporabnik pa ima vedno možnost izključiti prikaz vsebine tezavra.
} 
quick - definitions and thesaurus

( 89

ADJECTIVE Pronunciation / kwIk/ Word Forms

1 able to move fast or do something fast

He's surprisingly quick for such a big man.

a quick worker

T Synonyms and related words for this sense of quick

Words used to describe fast movement: fast, quick, swift, speedy, nimble, brisk, high-speed, agile, deft, at full speed/tilt/peltthrottle... More

a. able to understand things very easily

a quick learner

T Synonyms and related words for this sense of quick

Words used to describe intelligent or wise people: genius, intelligent, wise, brilliant, clever, bright, brainy, discerning. clear-sighted, no/nobody's fool... More

Slika 1: Hkraten prikaz vsebine slovarja in tezavra (sivo polje) v Macmillan English Dictionary.

Temeljno vprašanje pri vsakem večslovarskem viru je določitev hierarhije slovarjev in s tem tudi členitev ciljnih uporabnikov. Kateri slovar bo dobil osrednjo vlogo in s tem prvo mesto med rezultati iskanj? Po katerem kriteriju bodo razvrščeni drugi slovarji? Ali in kako bomo rezultate iskanj razvrščali glede na uporabnika? S tem je povezana tudi odločitev o obliki prikazovanja zadetkov: pri prikazu zadetkov iz vseh slovarjev na eni strani je lahko uporabnik soočen $\mathrm{z}$ dolgotrajnim pomikanjem po strani navzdol; pri prikazu zadetkov v zavihkih pa ne more primerjati zadetkov v različnih virih. Kot je pokazala raziskava Müller-Spitzer idr. (2012), ${ }^{15}$ imajo uporabniki najraje prikaz v

15 Sicer o rabi slovarskih portalov vemo bolj malo, saj se raziskave večinoma osredotočajo na učinkovitost in rabo posameznih slovarjev. 
zavihkih in prikaz v obliki strani z več okni, precej manj pa linearni prikaz zadetkov (imenujejo ga tiskani prikaz). Pri prikazovanju zadetkov v zavihkih uporabnik takoj ve, vsebina katerega slovarja mu bo najprej ponujena. Takšen pristop uporablja spletna stran Collins Dictionaries (Slika 2). Poleg tega informacije iz različnih slovarjev ne tekmujejo med seboj za prostor na zaslonu.

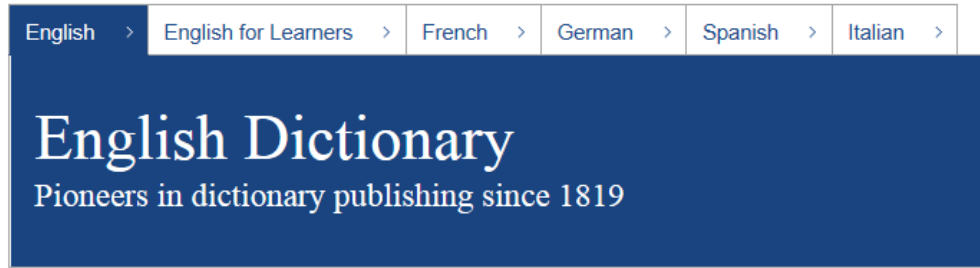

Your search found: conduct I Usaqe examples / Trends

\section{conduct}

\section{- Definitions}

noun

('kond^kt 咯) )

1. the manner in which a person behaves; behaviour

2. the way of managing a business, affair, etc; handling

3. (rare) the act of guiding or leading

4. (rare) a guide or leader

Slika 2: Zavihki na portalu Collins Dictionaries.

Odločitev o osrednjem slovarju portala je na nekaterih portalih, zlasti takih z večjezičnimi viri, (do določene mere) prepuščena uporabniku oziroma skuša portal avtomatično ugotoviti uporabnikovo preferenco. Na portalu Oxford Dictionaries je izbira osrednjega slovarja odvisna od izbire jezika (v času pisanja prispevka jih je bilo na voljo šest: angleščina, arabščina, francoščina, italijanščina, nemščina in španščina), pri čemer je privzeta nastavitev uradni jezik države, iz katere uporabnik dostopa do strani. ${ }^{16}$ Iskalnik nadalje prilagaja

\footnotetext{
${ }^{16}$ Spletni portal po vsej verjetnosti določi privzeti jezik na podlagi uporabnikovega IP-naslova.
} 
zadetke glede na iskanje: če uporabnik išče besedo ali besedno zvezo, ki je v osrednjem slovarju ni, mu iskalnik ponudi sestavek iz slovarja, v katerem najde zadetke. ${ }^{17}$ Uporabnik ima tudi možnost, da pred aktiviranjem iskanja s pomočjo sprotnega iskanja, ${ }^{18}$ ki zadetke razvrsti po slovarjih, izbere zadetke točno določenega slovarja (Slika 3).

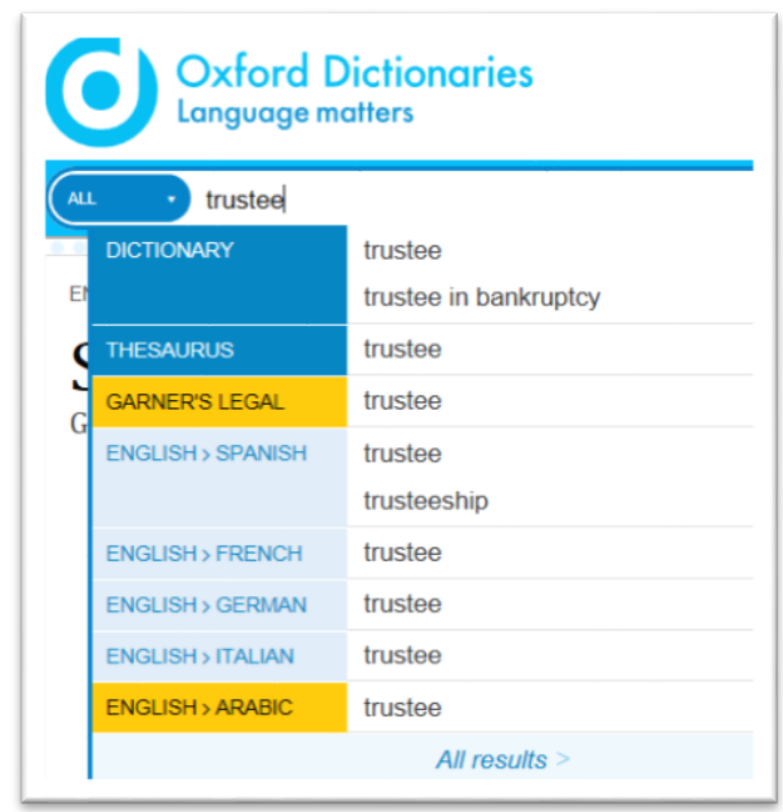

Slika 3: Rezultati sprotnega iskanja na portalu Oxford Dictionaries.

V vsakem primeru za slovarske portale velja nevarnost preobremenitve slovarskega uporabnika z informacijami (Tarp 2009). Ta nevarnost je prisotna že pri prikazovanju vsebin posameznega slovarja, zlasti prostorsko potratnih delov mikrostrukture, kot so npr. zgledi, kar pomeni, da je pri prikazovanju zadetkov iz več slovarjev količini informacij, ki je prikazana uporabniku, treba nameniti še toliko večjo pozornost. V zvezi s tem je relevantno tudi opažanje, da

\footnotetext{
17 Glede na vrstni red slovarjev v sprotnem iskanju, se zdi, da je razvrstitev slovarjev sledeča: splošni enojezični slovar, tezaver, specializirani enojezični slovarji in dvojezični slovarji. ${ }^{18}$ Sprotno iskanje sicer ponujajo skoraj vsi predstavljeni slovarski portali, le da brez delitve zadetkov po vsebovanih slovarjih.
} 
na spletnih straneh komercialnih ponudnikov zaslon dodatno obremenjujejo oglasi, ki niso povezani s slovarskimi vsebinami, jim pa kradejo dragocen prostor.

\subsection{Slovenski slovarski portali}

Strani, ki združujejo slovarje na enem mestu, že nekaj časa obstajajo tudi v slovenskem prostoru. Vzpostavitev različnih prostodostopnih jezikovnih portalov, kot so spletni portal s čim več podatki o slovenščini, večjezični portal in terminološki portal, je omenjena tudi v Resoluciji o nacionalnem programu za jezikovno politiko (2014-2018). V nadaljevanju bomo na kratko pregledali najbolj znane vire z več slovarji pri nas, z izjemo portala Fran, ki ga podrobneje predstavljamo $\mathrm{v}$ naslednjem razdelku prispevka.

Slovarski portal z največ slovarji je Termania ${ }^{19}$ podjetja Amebis, ki trenutno omogoča brezplačen dostop do 44 splošnih in terminoloških enojezičnih ter večjezičnih slovarjev, med drugim tudi do Slovarja slovenskega knjižnega jezika (SSKJ) in Slovenskega pravopisa 2001 (SP). Portal ponuja enostavno in napredno iskanje ter omogoča filtriranje rezultatov po izvornem jeziku, ciljnem jeziku in slovarjih. Koristna lastnost portala, ki je nismo zasledili pri nobenem drugem tujem ali domačem portalu, je prikaz »skrajšanih gesel « s podatki, ki uporabnika običajno zanimajo (iztočnico, prevod(i) in definicijo) (Romih in Krek 2012), iz različnih slovarjev (Slika 4), kar omogoča prikaz večjega števila zadetkov na eni strani in posledično hitrejši dostop do iskanih informacij. Ključno vlogo pri tem igra razvrščanje zadetkov, ki upošteva štiri kriterije: izbrani jezik vmesnika, mesto zadetka $\mathrm{v}$ geselskem članku, težo oz. pomembnost slovarjev ali gesel in abecedni vrstni red (Romih in Krek 2012: 164). Uporabniki mobilnih telefonov z operacijskim sistemom Android ali iOS (iPhone) lahko do Termanie dostopajo s pomočjo posebne aplikacije. 


\begin{tabular}{|lc|}
\hline naprava & Najdi \\
\hline Potrebujete posebne znake? Prikaži tipkovnico. & Napredno iskanje \\
\hline
\end{tabular}

\section{naprava - 1917 najdenih rezultatov ( 0.30 sekunde).}

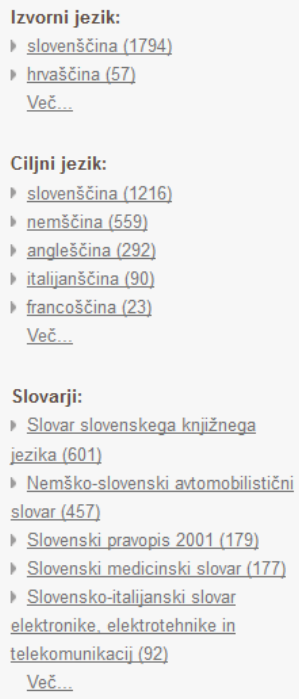

\section{napráva}

1. predmet, navadno večji, iz več sestavnih delov, ki omogoča, olajšuje, opravlja delo

2. izdelava, zgraditev

3. ustanova, institucija

4. oprava, obleka

5. (gospodarsko) poslopje, stavba ... več...

vir: Slovar slovenskega knjižnega jezika - SAZU in ZRC SAZU, Inštitut za slovenski jezik Frana Ramovša in avtorji

sil naprava (samostalnik)

en device, gadget, gear, set, implement, apparatus, institution, foundation

ce Gerät, Anlage, Einrichtung, Vorrichtung, Institution, Anstalt

sq institucion

fir dispositif, appareil, institution ... več...

vir. Presisov večjezični slovar - Amebis, d. o. o., Kamnik

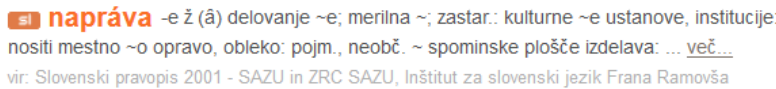

naprava (samostalnik) aparat; ustanova, institucija, institut, fundacija .... več... vir. Amebisov slovar sopomenk - Amebis, d. 0. o. Kamnik

Slika 4: Prikaz izsekov gesel na portalu Termania.

Drugi portal, ki ga velja omeniti, je Pons ${ }^{20}$ založbe Klett, ki ponuja dostop do številnih dvojezičnih slovarjev, nemškega pravopisa in šolskega slovarja ter nemškega in angleškega slikovnega slovarja. Dvojezični slovarji s slovenščino kot izhodiščnim ali ciljnim jezikom so na voljo za angleščino, francoščino, italijanščino, nemščino in španščino. Uporabniku je na voljo samo enostavno iskanje, ki je zasnovano tako, da mora uporabnik najprej izbrati jezikovni par oz. slovar, ki ga zanima. Koristna funkcija iskanja je izpis rezultatov za besede s podobnim zapisom ( $\mathrm{v}$ obeh jezikih jezikovnega para) $\mathrm{v}$ primeru, ko za iskani niz

20 http://sl.pons.com 
v izbranem slovarju ni zadetkov (Slika 5). Vsaka beseda v izpisu zadetkov je klikljiva, kar omogoča hiter vpogled v prevod. Kot pri Termanii je tudi dostop do portala Pons možen prek mobilnih aplikacij (za operacijske sisteme Android, iOS in Windows 8). Moteč del portala pa so oglasi, ki se ne pojavljajo samo ob straneh z rezultati iskanj, kot na tujih portalih, ampak tudi med samimi rezultati (Slika 5).

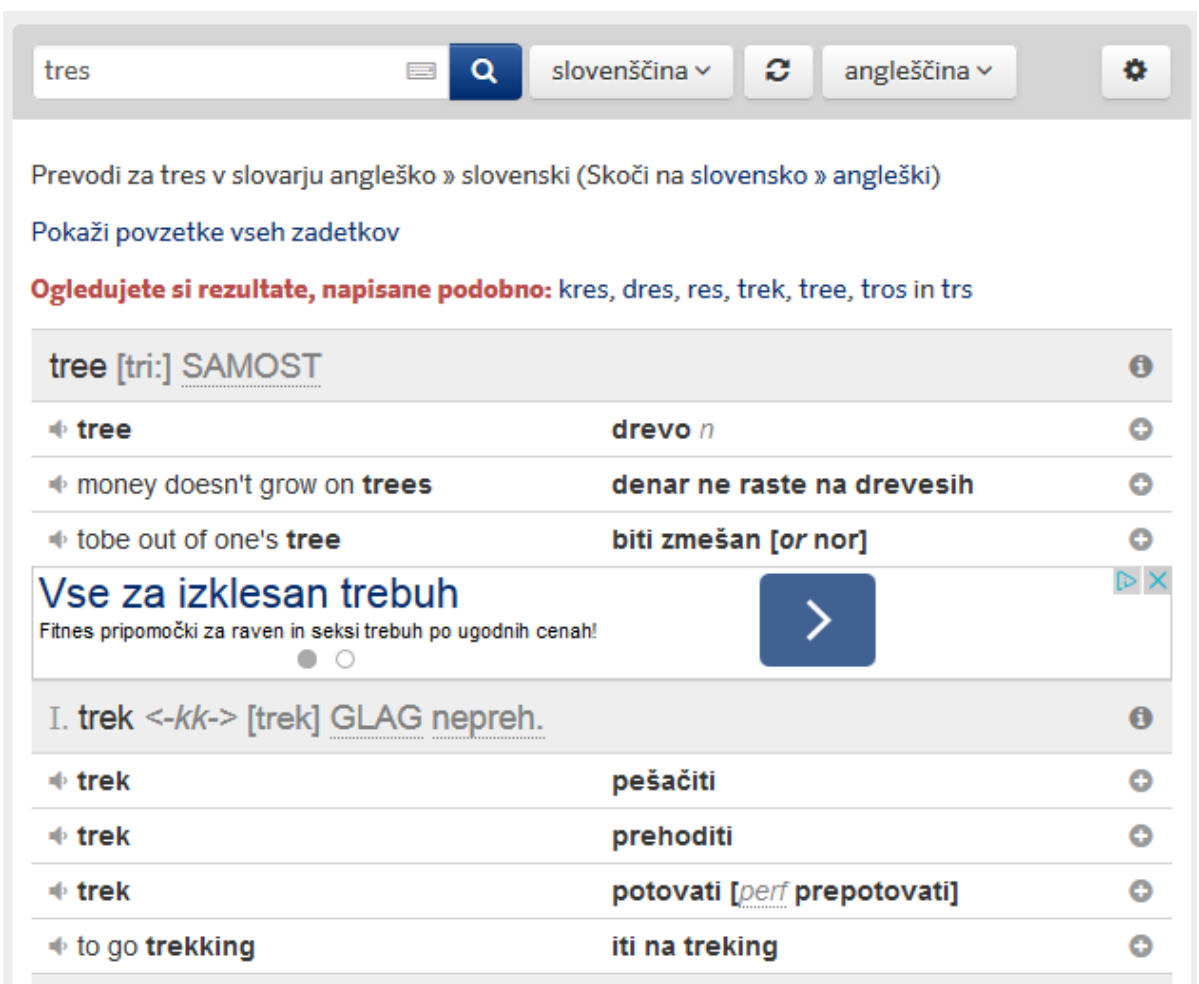

Slika 5: Izpis rezultatov za besede s podobnim zapisom na portalu Pons.

Tretji zanimiv slovenski portal je večjezična terminološka zbirka Evroterm, ${ }^{21}$ ki vsebuje 503.465 izrazov v 17 evropskih jezikih, zanjo pa trenutno skrbi Generalni sekretariat Vlade Republike Slovenije. Evroterm večinoma vključuje izbrano izrazje iz prevodov dokumentov EU, zbirki pa so dodani tudi preverjeni

21 http://www.evroterm.gov.si/ 
slovarji in glosarji. Ciljni uporabniki Evroterma so prevajalci in terminologi. Enostavno iskanje omogoča iskanje po vseh izbranih jezikih (privzeto je iskanje po angleščini, francoščini, italijanščini, nemščini in slovenščini), pri čemer se kot rezultat prikaže zadetek, ki najbolje ustreza iskanemu nizu, ob strani pa se izpišejo še vsi zadetki, ki iskani niz zgolj vsebujejo (Slika 6). Uporabniki lahko tudi prilagodijo nastavitve iskanja, tako da izberejo jezike, po katerih želijo iskati, in podatke, ki naj se izpišejo. Izpopolnjeno iskanje omogoča vnaprejšnjo določitev različnih parametrov, npr. jezikovnega para in področja, iskanje samo določenega izraza ali pregibnih oblik ter pojmov, ki so enaki iskanemu izrazu, se začnejo ali končajo na iskani izraz, vsebujejo iskani izraz itd. Uporabnikom mobilnih telefonov je Evroterm na voljo v posebni spletni različici ali pa $\mathrm{v}$ okrnjenem obsegu v programu za mobilne telefone in računalnike, ki pa je preizkušen samo na (starejših) telefonih Nokia. 


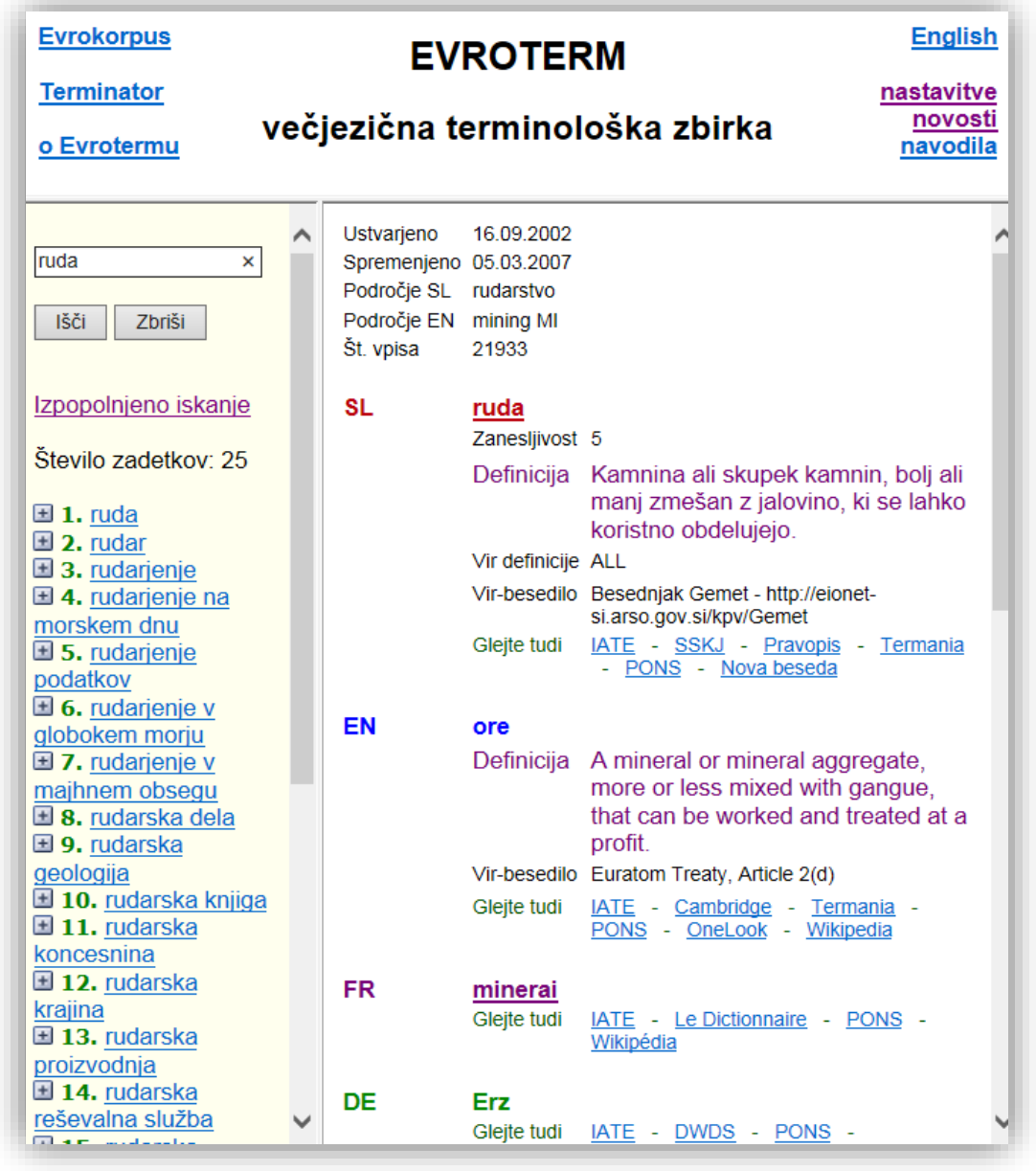

Slika 6: Izpis zadetkov v Evrotermu.

Od slovarskih portalov velja omeniti še portal e-slovarji založbe DZS, ${ }^{22}$ na katerem najdemo velike in male dvojezične slovarje $\mathrm{s}$ kombinacijami slovenščine ter angleščine, francoščine, italijanščine, nemščine, srbščine in španščine. Iskalnik omogoča iskanje po iztočnici, sestavkih ali levo in desno od iztočnice. Rezultate iskanja dobi uporabnik v obliki seznama slovarjev in števila zadetkov, najdenih v posameznem slovarju. Po izbiri želenega slovarja se 
prikaže prvi zadetek oz. sestavek, pri čemer so sestavki razvrščeni po abecedi (Slika 7), kar ni ravno dober kriterij za odkrivanje najverjetnejšega rezultata oz. sestavka, ki ga išče uporabnik.

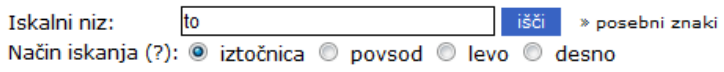

Veliki nemško-slovenski e-slovar
Veliki slovensko-nemški e-slovar
Veliki italijansko-slovenski e-slovar
Veliki slovensko-italijanski e-slovar
Mali angleško-slovenski e-slovar
Mali slovensko-angleški e-slovar
Mali srbsko-slovenski e-slovar
Mali slovensko-srbski e-slovar
Francosko-slovenski e-slovar
Slovensko-francoski e-slovar
Špansko-slovenski e-slovar
Slovensko-španski e-slovar
Geslo

day-to-day [déitudéi] adj vsakodneven, vsakdanji

Iztočnice (prvih
day-to-day
down-to-earth
house-to-house
one-to-one
set-to
to
to-do
well-to-do

Slika 7: Izpis rezultatov za iskani niz to v Malem angleško-slovenskem e-slovarju DZS (demo različica).

Edini slovarski agregator pri nas, vsaj kolikor je avtorju znano, je vzporedni iskalnik po Slovenskem pravopisu, SSKJ ter korpusih Nova Beseda in Gigafida, ${ }^{23}$ katerega avtor je Miran Željko. Miran Željko je tudi avtor in skrbnik daleč največje zbirke slovarskih povezav ${ }^{24}$ pri nas, v kateri najdemo povezave do več kot 1.100 prostodostopnih slovarjev, glosarjev, portalov, korpusov in podobnih splošnih in terminoloških jezikovnih virov.

\footnotetext{
23 http://m.anyterm.info/praslon.php

24 http://www.evroterm.gov.si/slovar/index.html
} 
Med zbirke slovarskih povezav uvrščamo tudi Terminologišče, ${ }^{25}$ kjer najdemo povezave do terminoloških slovarjev Sekcije za terminološke slovarje Inštituta za slovenski jezik Frana Ramovša ZRC SAZU. Čeprav gre za enotno vstopno točko do vseh slovarjev, ne moremo govoriti o slovarskem portalu, saj je vsak slovar (prek povezave) ponujen na ločeni strani - iskanje po vseh slovarjih hkrati pa tu ni mogoče. Je pa to mogoče na portalu Fran, ki mu v nadaljevanju namenjamo več pozornosti.

\section{PORTAL FRAN 26}

Portal Fran ${ }^{27}$ Inštituta za slovenski jezik Frana Ramovša ZRC SAZU (ISJFR) je začel delovati 14. oktobra 2014 in trenutno nudi dostop do 20 splošnih, zgodovinskih in terminoloških slovarjev, Slovenskega lingvističnega atlasa, dveh svetovalnic (jezikovne in terminološke) in posredno tudi do zadetkov v različnih besedilnih zbirkah (korpusih Gigafida, Nova Beseda, Kres in Gos ter O'beseda) in besednih zbirkah (besede slovenskega jezika, Besedišče slovenskega jezika). Vsi slovarji na portalu Fran so enojezični, terminološki slovarji pa ponujajo tudi ustreznike $\mathrm{v}$ tujih jezikih (angleščini, nemščini, francoščini, italijanščini in/ali latinščini). Skupno število slovarskih sestavkov na portalu je 513.432. Kot je razvidno iz razdelitve sestavkov po posameznih virih, prikazanih na Sliki 8, splošni slovarji predstavljajo na portalu več kot polovico sestavkov (56,5 \%), zgodovinski tretjino (33,5 \%), terminološki slabo desetino (9,5 \%), Slovenski lingvistični atlas manj kot pol odstotka (o,4 \%), najmanj pa sestavki oz. odgovori jezikovnih svetovalnic (o,1 \%).

\footnotetext{
25 http://isjfr.zrc-sazu.si/sl/terminologisce/slovarji

${ }^{26}$ Mnenja, pridobljena pri testiranju portala, so izključno avtorjeva; dobro bi bilo izvesti več usmerjenih testiranj pri različnih uporabnikih. Portal smo testirali med 28. 12. 2014 in 31. 12. 2014.

27 http://www.fran.si
} 
Slovarji

\begin{tabular}{lll} 
SSKJ & 93154 & 93154 \\
SNB & 5382 & 5100 \\
SSSJ & 225 & 225 \\
SSKJ ${ }^{2}$ & 97669 & 96917 \\
Pravopis & 92615 & 92615 \\
SPT & 1098 & 0 \\
\hline Zgodovinski & 171920 & 170419 \\
\hline Pleteršnik & 103185 & 103185 \\
\hline Prekmurski & 14849 & 14849 \\
\hline Vorenc & 17666 & 16398 \\
Svetokriški & 8461 & 8446 \\
Besedje16 & 27759 & 27541 \\
Terminološki & 48606 & 38175 \\
\hline Botanika & 6693 & 5306 \\
\hline Farmacija & 5549 & 4510 \\
\hline Smučanje & 4014 & 3292 \\
Gledališče & 2950 & 2235 \\
\hline Čebelarstvo & 3073 & 2208 \\
Geologija & 10803 & 8392 \\
Gemologija & 3025 & 2432 \\
Geografija & 8891 & 6843 \\
Planinstvo & 3608 & 2957 \\
SLA 1 & 2120 & 0 \\
\hline
\end{tabular}

Svetovanje:

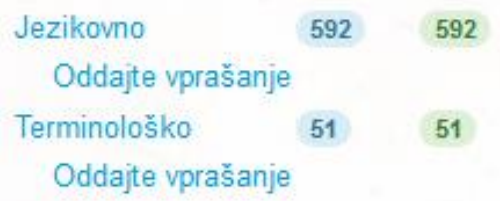

Slika 6: Število sestavkov po viru na portalu Fran. 
Skoraj vsi slovarji na portalu Fran so prosto dostopni; izjema je le nedavno izdani SSKJ2 (2014), ki predstavlja skoraj petino sestavkov na portalu in je dostopen z uporabo kode, ki jo uporabnik dobi ob nakupu tiskane verzije slovarja. Razen SSKJ2, ki zaradi plačljivega dostopa gotovo ne bo imel toliko uporabnikov, kot bi jih imel, če bi bil prosto dostopen, na portalu v kategoriji splošnih slovarjev ni veliko slovarjev, ki že do zdaj ne bi bili na voljo na spletu in brez plačila. Izjemi sta Sprotni slovar slovenskega jezika in Slovar pravopisnih težav, ki pa vsebujeta majhno število gesel, zato je njuna uvrstitev med splošne slovarje vprašljiva, poleg tega pa gre za nedavna izdelka. Osrednja lastnost portala je torej predvsem ta, da na enem mestu združuje nekatere že prej obstoječe enojezične slovarske vire, ki so v preteklih letih (več desetletjih) nastajali na ISJFR. Bistvena novost Frana torej ni v njegovi vsebini, temveč v tehnični pridobitvi: enotnem iskalniku in posledično novem vmesniku. Velja pa opozoriti že tudi na omejitev, ki je pri zgoraj opisovanih portalih nismo zasledili: za določene slovarje na portalu Fran ne velja prikaz sestavka v celoti, saj so npr. zadetki iz terminoloških slovarjev izpisani zgolj kot iztočnice, celoten sestavek pa si uporabnik lahko ogleda le na strani slovarja v Terminologišču, kamor se mora priklikati ločeno.

\subsection{Ciljni uporabnik(i) portala}

Če upoštevamo raznolikost slovarjev na portalu Fran in zasnovo vmesnika, lahko predvidevamo, da bodo uporabniki portala zelo raznorodni, od manj zahtevnih do naprednejših, ki se tako ali drugače ukvarjajo z jezikom, npr. lektorji, prevajalci, terminologi in jezikoslovci. Portal vsebuje vire za uporabnike, ki jih zanima splošni jezik, stara slovenščina ali terminološko izrazje. Na podlagi privzetih nastavitev portala lahko sklepamo, da ima prednost laični uporabnik, ki ga zanima splošni jezik; to je razvidno tako iz uvodne strani, kjer so pod iskalnim oknom prikazani splošni slovarji, kot tudi iz razvrščanja rezultatov iskanj, kjer so najprej prikazani zadetki iz splošnih slovarjev, sledijo jim zadetki iz zgodovinskih in terminoloških slovarjev ter jezikovnih svetovalnic. 


\subsection{Vmesnik in iskalnik}

Naslovna stran portala in celotna grafična podoba sta izčiščeni, enostavni in sodobno zasnovani, kar bo razveselilo mnoge uporabnike, ki so se do zdaj srečevali z zastarelo podobo spletnih strani SSKJ in SP. Osrednji del naslovne strani je namenjen iskalnemu oknu in prikazu naslovnic slovarjev (privzet je prikaz splošnih slovarjev), ki so obenem povezave na posamezni slovar. Uporabnikom manj prijazna je umestitev povezav na ostale dele portala. Povezave na napredno iskanje, naslovno stran (Vsi slovarji), podatke o portalu (O Franu) in registracijo (Prijava) niso tam, kjer jih običajno pričakujemo. Zlasti umestitev povezav na naslovno stran in registracijo se zdi vprašljiva, saj so na pregledanih domačih in tujih slovarskih portalih, pa tudi na ostalih spletnih straneh, ki zahtevajo registracijo, tovrstne povezave običajno v desnem zgornjem kotu zaslona.

Portal uporablja zgolj štiri barve: črno, sivo, modro in zeleno. Črna in siva (slednja v več odtenkih) sta uporabljeni za vsebino slovarskih gesel, pri čemer je črna namenjena pomembnejšim delom mikrostrukture, npr. v SSKJ in SSKJ2 je uporabljena za razlage. Uporaba črne v krepkem tisku je omejena na latinske besede in izraze v Slovensko-latinskem slovarju (Kastelec in Vorenc, 1608-1710). Modra barva je namenjena vsem klikljivim delom portala, tj. slovarskih iztočnicam $\mathrm{v}$ zadetkih, ki nudijo povezavo do ločenega ogleda sestavka v slovarju, slovarjem v filtrih, gumbom za premikanje po straneh z zadetki, povezavi na napredno iskanje, povezavam na korpuse itd. Poleg tega je modra ( $\mathrm{v}$ poševnem slogu) uporabljena $\mathrm{v}$ SP za sopomenke. Zelena je namenjena prikazu števila zadetkov zunaj (pod)iztočnic $\mathrm{v}$ filtrih in povezavi za ogled celotnega sestavka v Sprotnem slovarju slovenskega jezika in Slovarju pravopisnih težav. Omejitev na majhno število barv se zdi smiselna, ne pa tudi način njihove izrabe. Pri prikazu zadetkov namreč prevladuje siva barva, ki otežuje branje tudi zaradi dejstva, da je ozadje portala sivo. Postavlja se tudi vprašanje, zakaj določeni deli gesel, npr. kvalifikatorji, niso označeni z drugo 
barvo, saj raziskave kažejo, da barvni kvalifikatorji povečajo uspešnost iskanja želenih slovarskih informacij in povečajo retencijo informacij pri uporabnikih (Dziemianko 2015).

\subsubsection{ISKALNIK}

Portal omogoča enostavno iskanje, ki je privzeti način iskanja in išče po iztočnicah ter podiztočnicah, in napredno iskanje, ki je na voljo prek povezave. Enostavno iskanje omogoča sprotno iskanje, ki uporabniku med tipkanjem iskanega niza sproti kaže obstoječe slovarske iztočnice. Del iskalnega okenca je tudi gumb za aktiviranje tipkovnice, ki omogoča vnos posebnih znakov (naglasov ipd.). Napredno iskanje uporabniku omogoča, da iskanje omeji na vrsto slovarjev (splošni, zgodovinski ipd.), na posamezne slovarje ali samo na en slovar ter na dele gesel (vse, iztočnica, razlaga, zgled ipd.). Koristna funkcija naprednega iskanja je, da se ob izbiri slovarja ali slovarjev osvetlijo iskalna okenca samo pri tistih delih sestavka, po katerih uporabnik lahko išče. Oba način iskanja omogočata tudi uporabo regularnih izrazov (? nadomesti eno črko, * nadomesti poljuben niz črk), česar pa avtorji portala ne izpostavljajo, saj najdemo podatek samo $\mathrm{v}$ odgovorih na pogosta vprašanja na delu strani $\mathrm{s}$ podatki o portalu. Uporabniku prijazna je tudi rešitev, da ostaja iskalna vrstica na vrhu tudi med premikanjem po zadetkih navzdol.

Pri testiranju se je kot ena večjih pomanjkljivosti enostavnega iskanja pokazala odsotnost možnosti omejitve iskanj po skupinah slovarjev, zlasti po splošnih slovarjih, saj tudi kasneje pri rezultatih tega filtri ne omogočajo (glej 3.2.3). Moteče je predvsem to, da se uporabnik ne more na enostaven način znebiti podatkov iz zgodovinskih slovarjev, terminoloških slovarjev in/ali narečnega slovarja in se osredotočiti zgolj na podatke o splošni slovenščini (glej tudi naslednji razdelek o razvrščanju zadetkov). Moteče za uporabnika je tudi dejstvo, da se pri naprednem iskanju, ki takšna iskanja omogoča, nastavitve ne shranijo in jih je treba pri vsakem iskanju na novo določati. Shranjevanje nastavitev naprednih iskanj je na voljo le ob registraciji, kar pa med uporabniki 
jezikovnih virov ni priljubljena možnost in jo bodo na portalu Fran najbrž uporabljali večinoma le kupci SSKJ2.

Kot izpostavljata Lew in Mitton (2011), je dober (in intuitiven) iskalnik po slovarju tisti, ki zna uporabniku pomagati tudi v primerih, ko iskani niz ne najde popolnega ujemanja med slovarskimi (pod)iztočnicami bodisi zaradi uporabnikove slabše jezikovne zmožnosti, napake pri vnosu ali zaradi načina strukturiranosti slovarskih informacij. Zato smo preizkusili dva scenarija:

- iskanje napačno črkovanih besed;

- iskanje niza, ki ne obstaja kot (pod)iztočnica.

V prvem primeru smo preizkusili iskanja napačno črkovanih besed, pri čemer smo se opirali na najpogostejše napake črkovanja v korpusu Šolar. ${ }^{28}$ Hoteli smo namreč videti, ali bi portal pomagal šolarjem pri identifikaciji napak in iskanju ustreznih rešitev. ${ }^{29} \mathrm{Na}$ prvi pogled so rezultati spodbudni, saj samo v dveh primerih (mišlenje in biu) iskanje ne vrne zadetkov ali ponudi alternativ oz. približkov (Tabela 1). $\mathrm{V}$ trinajstih primerih iskanje vrne zadetke, a v večini primerov iz zgodovinskih slovarjev, kar pa šolarjem zelo verjetno ne bo pomagalo; še več, obstaja nevarnost napačne interpretacije, saj bi ob slabšem poznavanju specifike posameznih slovarjev ali površnem pregledovanju rezultatov, lahko (šolski) uporabnik pomislil, da je določena oblika ustrezna. V preostalih primerih iskanje ne vrne zadetkov, ponudi pa približke in v osmih od desetih primerov je ustrezna oblika prva od ponujenih približkov. Težava nastopi, ko si želi uporabnik ogledati zadetke za približek, saj se izvede iskanje ponujene oblike (npr. domov) po vseh delih gesel, rezultati pa se izpišejo po abecednem vrstnem redu, ne pa po relevantnosti. Tako recimo slovarske sestavke za domov najdemo na drugi strani zadetkov, za vztrajati na četrti

\footnotetext{
28 Podatki so bili pridobljeni iz frekvenčnega seznama napak v vmesniku korpusa Šolar (http://www.korpus-solar.net/), deloma pa tudi iz Kosem idr. (2012).

29 O tem, da bodo portal Fran najbrž uporabljali tudi šolarji, priča dejstvo, da je bil Fran eden od virov, predstavljenih učiteljem na delavnicah v okviru projekta Jezikovnotehnološko izobraževanje učiteljev (2014), ki ga je financiralo Ministrstvo za kulturo RS.
} 
strani itd.

\begin{tabular}{|c|c|c|c|}
\hline Oblika & Rezultat & Slovar(ji) & Ponujene alternative \\
\hline use & da & Besedje16 (zgodovinski) & \\
\hline bol & da & razni slovarji & \\
\hline kod & da & razni slovarji & \\
\hline domol & ne & & da (domov na prvem mestu) \\
\hline ušeč & ne & & da (všeč ni na seznamu) \\
\hline teško & da & $\begin{array}{l}\text { Prekmurski in Besedje16 } \\
\text { (zgodovinska slovarja) }\end{array}$ & \\
\hline življenski & da & Pleteršnik (zgodovinski) & \\
\hline vrjeti & ne & & da (verjeti na prvem mestu) \\
\hline gdo & da & $\begin{array}{l}\text { Prekmurski in Besedje16 } \\
\text { (zgodovinska slovarja) }\end{array}$ & \\
\hline usi & da & $\begin{array}{l}\text { Prekmurski in Besedje16 } \\
\text { (zgodovinska slovarja) }\end{array}$ & \\
\hline pribljižno & ne & & da (približno na prvem mestu) \\
\hline usak & da & Besedje16 (zgodovinski) & \\
\hline mišlenje & ne & & ne \\
\hline gdaj & ne & & da ( $k d a j$ ni na seznamu) \\
\hline popolen & da & Besedje16 (zgodovinski) & \\
\hline jast & da & $\begin{array}{l}\text { Svetokriški in Besedje16 } \\
\text { (zgodovinska slovarja) }\end{array}$ & \\
\hline$z d e j$ & ne & & da (zdaj na prvem mestu) \\
\hline usaj & $\mathrm{da}$ & Besedje16 (zgodovinski) & \\
\hline
\end{tabular}




\begin{tabular}{l|l|l|l}
\hline uprašati & da & Besedje16 (zgodovinski) & \\
\hline najbol & ne & da (najbolj na prvem mestu) \\
\hline bolši & da & $\begin{array}{l}\text { Prekmurski in Besedje16 } \\
\text { (zgodovinska slovarja) }\end{array}$ & \\
\hline biu & ne & ne & da (̌̌ivljenje na prvem mestu) \\
\hline živlenje & ne & da (vztrajati na prvem mestu) \\
\hline vstrajati & ne & da (vseeno na prvem mestu) \\
\hline vseno & ne & & \\
\hline
\end{tabular}

Tabela 2: Rezultati iskanj pogostih napak črkovanja (vir korpus Šolar) na portalu Fran.

Pri iskanju nizov, ki ne obstajajo kot (pod)iztočnice, smo iskali dvoje: besede v neiztočničnih oblikah (različnih sklonih ipd.) in večbesedne zveze. Pri takšnih iskanjih so rezultati dveh tipov: iskanje ne vrne zadetkov, so pa ponujeni približki, ali iskanje ne vrne zadetkov in pokaže število zadetkov zunaj (pod)iztočnic v filtrih. Če vzamemo za primer samostalnik sobota, so za oblike soboti, sobot, sobotama, sobotam in sobotami ponujeni približki (pri čemer za sobotama in sobotami ni ponujen približek sobota), za oblike sobote, soboto, sobotah pa ni zadetkov in so na voljo le povezave $\mathrm{v}$ filtrih na zadetke zunaj iztočnic. Od uporabnika je torej bolj ali manj pričakovano, da bo v iskalnik vedno vtipkal osnovno obliko besede.

Pri večbesednih nizih se pokaže zlasti slabost SSKJ in SSKJ2, ki ne obravnavata večbesednih zvez na ravni (pod)iztočnic (kar pa ne velja za SNB). Posledično je veliko iskanj večbesednih nizov neuspešnih, razen seveda, če obstajajo zadetki $\mathrm{v}$ zgodovinskih in terminoloških slovarjih. Morda bi namesto obvestila o neuspešnem iskanju in napotitvi na filtre veljalo kar prikazati zadetke zunaj (pod)iztočnic in uporabniku prihraniti dodatno klikanje, sploh če zadetkov ni veliko in so omejeni le na nekaj slovarjev, kot je npr. pri zvezi dnevna soba (12 zadetkov v treh virih: SSKJ2, SSKJ in SP). 


\subsubsection{PRIKAZ IN RAZVRŠČANJE ZADETKOV}

Zadetki na portalu Fran so prikazani na način, ki je glede na kategorizacijo v Müller-Spitzer idr. (2012) še najbližje tiskanemu prikazu. Razlike med tiskano različico slovarjev in njihovimi elektronskimi verzijami v Franu so minimalne, npr. pomeni v SSKJ in SP se začnejo vsak v svoji vrsti, podiztočnice v SNB so v svoji vrsti ter zamaknjene ipd. Tako prikazani sestavki vsebujejo rešitve za varčevanje $\mathrm{s}$ prostorom (in stranmi) pri tisku, ki so $\mathrm{v}$ elektronski obliki nepotrebne in uporabniku precej manj prijazne, npr. uporaba tilde $(\sim)$ namesto iztočnice v SP ali okrajšanih oblik kvalifikatorjev v SSKJ. Avtorji pri snovanju portala očitno niso upoštevali ugotovitev raziskav o rabi elektronskih slovarjev, saj je tiskani prikaz slovarskih podatkov med uporabniki daleč najmanj priljubljen (Müller-Spitzer 2012).

Del prikaza zadetkov je tudi funkcija sprotnega razlaganja slovarskih kratic in zgradbe slovarskih sestavkov, ki se aktivira, ko se z miškinim kazalcem ustavimo na določenem delu sestavka. Pomoč pri razlaganju slovarskih kratic bo za uporabnike dobrodošla, saj je težko pričakovati, da bodo šli pojasnila iskat na stran z informacijami o slovarju. Po drugi strani je razlaganje zgradbe sestavkov manj potrebno, saj so slovarski uporabniki osredotočeni na slovarsko vsebino in ne zgradbo slovarja. Funkcija sicer (zaenkrat) deluje samo pri splošnih slovarjih, ne pa tudi pri zgodovinskih slovarjih, kjer bi bila mogoče celo bolj smiselna. Njeno delovanje je najbolj zanesljivo pri zadetkih v SSKJ, SSKJ2 in SNB, manj pa pri zadetkih iz SP. Težave se pojavijo predvsem pri doslednosti, saj ima včasih prednost razlaga zgradbe in ne kratice (Slika 7), in pravilnosti označevanja, ko se označi prevelik del zgradbe (Slika 8). Pri testiranju se je pokazalo tudi, da nenehno označevanje delov gesel in prikaz pojavnih okenc z razlagami postane moteče in celo otežuje branje vsebine (gl. razdelek 3.2.5).

\section{velíki -a -o sam.jnar. véliki: zgodilo se je nekaj velikega; eni kradejo po malem, drugi po velikem; preg. iz malega raste velikg vo vor 7 malim ni zadovoljen, velikega vreden ni; prim. več, večji, veliki, veliko Kvalifikator, pojasnilo}

Slika 7: Razlaga elementa zgradbe (in ne kratice) v SSKJ. 
dán ${ }^{1}$ dnéva $\mathrm{m}$, ed. tudi dán dné -évu - -évu -ém; -éva dni -éma -éva -éh -éma; -évi dni -ém dní -éh -évi

(â ề)

1. tretji v letu; in noč; sončen ; čez dva dni; Dober |pozdrav|; brezskrbni evi; evi mladosti

2. rojstni ; uradni evi; Prešernov ; državnosti; urad. dopis z dne 10. maja; Ljubljana, dne 26. 5

3. Za dne je prišel; K u zvoni; spati čez İ; Večkrat na ga vidi; $Z$ dnem je pritisnil mraz |proti jutru|; Ves se potepa;

na , za dnem, iz eva v , noč in misli na to |kar naprej, neprenehoma|

4. poud: Svoj živ(i) tega še nisem videl |še nikoli]; Do konca svojih dni ti bom hvaležen |do smrti|; Na z besedo

|povej, kaj misliš|; govoriti tja v en |brez premisleka|; Pri belem evu se je zgodilo |podnevi; ne skrivaj, javno|

Zgled $-a$-o (á) poud. stvari, e enkrat za vselej |dokončno določene, nespremenljive|

Slika 8: Napačno označen del zgradbe slovarja (v SP).

Za uporabnike spletnih strani je vedno nadležno, če povezave v brskalniku odpirajo nova okna ali jih preusmerjajo na druge spletne strani. Na portalu Fran tega ni malo, saj se uporabnik s tem sreča pri terminoloških slovarjih, jezikovnih svetovalnicah, pa tudi pri Slovenskem lingvističnem atlasu. Med odgovori na pogosta vprašanja najdemo skopo pojasnilo, da so uporabniki poslani na druge strani »zaradi specifičnosti terminološkega besedja in svetovalne dejavnosti«, kar se zdi bolj odraz organizacije slovarskega dela na inštitutu kot rešitev $\mathrm{v}$ korist uporabnika. Podobno pri Slovenskem lingvističnem atlasu ni jasno, zakaj se vsak dokument pri iztočnici (komentar, karta in gradivo h karti) odpre v ločenem oknu - veliko boljša bi bila namreč rešitev s prikazom vseh dokumentov ali vsaj karte in komentarja v modulih oz. ločenih oknih znotraj portala (kot npr. pri nemškem portalu DWDS), saj gre za povezane informacije.

Zadetki iskanj so razvrščeni po naslednjem zaporedju: najprej so prikazani zadetki iz vseh splošnih slovarjev, nato iz zgodovinskih, sledijo zadetki iz svetovalnic in terminoloških slovarjev. Ne glede na tip slovarja dobijo prednost zadetki, pri katerih se iskani niz pojavlja $\mathrm{v}$ iztočnici oz. pri svetovalnicah $\mathrm{v}$ krovnem vprašanju, sledijo jim zadetki z iskanim nizom $\mathrm{v}$ podiztočnici. To se zlasti pri SSKJ in SSKJ2 izkaže za problematično $\mathrm{v}$ primerih, ko iščemo pridevnike (npr. prenesen), ki so obravnavani na ravni podiztočnic $\mathrm{v}$ glagolskih sestavkih, saj so takšni zadetki potem prikazani za zadetki iz ostalih splošnih 
ter zgodovinskih in terminoloških slovarjev. ${ }^{30}$ Znotraj skupin slovarjev, tj. pri zgodovinskih in terminoloških slovarjih, so zadetki razvrščeni po abecednem vrstnem redu. Pri razvrščanju zadetkov iz splošnih slovarjev je uporabljen vrstni red slovarjev v filtrih (gl. Sliko 6), ki pa nima jasnega kriterija, saj vodilo ni aktualnost (SSKJ in SNB imata prednost pred SSKJ2), obseg (SNB ima prednost pred SSKJ2) ali referenčnost (SNB ima prednost pred SSKJ2 in SP).

\subsubsection{FILTRI}

Pomemben del okna z zadetki so filtri, ki imajo dvojno vlogo: prikazujejo število zadetkov $\mathrm{v}$ posameznih slovarjih in omogočajo filtriranje prikaza zadetkov na posamezen slovar, pri zgodovinskih in terminoloških slovarjih pa tudi na celotno skupino slovarjev. Vsaka slovarska vrstica v filtrih vsebuje tri povezave: ime slovarja ponudi vse sestavke $\mathrm{v}$ slovarju, razvrščene po abecedi, $\mathrm{z}$ iskanim nizom kjerkoli $\mathrm{v}$ sestavku, številka $\mathrm{v}$ modrem krogcu sestavke $\mathrm{S}$ (pod)iztočnicami z iskalnim nizom, številka v zelenem krogcu pa sestavke, kjer je iskalni niz najden zunaj (pod)iztočnic. Filtri niso novost v slovenskem prostoru, saj jih najdemo $\mathrm{v}$ slovarskem portalu Termania, pa tudi $\mathrm{v}$ konkordančnikih korpusov Gigafida, Kres in Gos. Filtri so v portalu Fran uporabljeni nekoliko drugače kot $\mathrm{v}$ omenjenih virih, vendar pa spremembe niso nujno koristne za uporabnike: tako se zdi umestitev filtrov na desno stran zaslona nenavadna, saj je glavna funkcija filtrov omejevanje zadetkov, kar uporabniku omogoča, da hitreje pride do želene informacije. Glede na prakso portalov, kjer so informacije ponavadi podane od leve proti desni, in posledično navajenost uporabnikov na takšen način branja informacij, s takšno postavitvijo filtrov avtorji portala spodbujajo uporabnike, da najprej pogledajo zadetke na levi in se šele kasneje zatečejo k uporabi filtrov.

Dobra se zdi odločitev, da je seznam slovarjev v filtrih stalen; pri rezultatih so tako vedno navedeni vsi slovarji, tudi tisti, v katerih iskalnik ni našel zadetkov.

${ }^{30} \mathrm{~V}$ večini primerov lahko težavo sicer rešimo s preklopom na razvrstitev po slovarjih (povezava nad filtri). 
Moti le to, da je tudi pri slovarjih brez zadetkov ime slovarja klikljivo, klik pa ne daje zadetkov. Mogoče bi bilo bolje povezavo odstraniti in celo osiviti ali drugače označiti slovarje brez zadetkov, da bi se lahko uporabniki osredotočili samo na slovarje z zadetki.

Pri testiranju smo v filtrih zelo pogrešali možnost omejevanja rezultatov na splošne slovarje (trenutno je na voljo samo filtriranje po posameznih splošnih slovarjih), sploh ker je to že na voljo za zgodovinske in terminološke slovarje. Tudi izkušnje z uporabniki, kot so učitelji (Jezikovnotehnološka izobraževanja učiteljev 2012-2014) in prevajalci, kažejo, da jih največkrat zanimajo podatki iz SSKJ (zdaj najbrž iz SSKJ2 in/ali, v primeru, da do SSKJ2 nimajo dostopa, iz $\mathrm{SNB}$ ) in SP. Navaditi se je treba tudi na tri različne povezave v vrstici filtra, saj se je avtorju prispevka večkrat zgodilo, da je pri filtriranju na zadetke $\mathrm{v}$ (pod)iztočnicah določenega slovarja instinktivno kliknil na ime slovarja in ne na podatek o število zadetkov v (pod)iztočnicah.

Del okna s filtri so tudi povezave na korpuse (npr. Gigafida, Kres, Nova Beseda) in besedne vire (npr. Besedišče slovarja slovenskega jezika), kar bo za uporabnike, ki bodo želeli še kakšno dodatno informacijo, zelo dobrodošlo. Pri tem je treba poudariti, da ne gre samo za povezave do spletnih strani omenjenih virov, ampak se uporabniku odpre že stran z zadetki iskanega niza v portalu Fran v izbranem viru. Kot pri filtrih, se tudi pri povezavah na korpuse pojavi težava, da je vir klikljiv tudi v primeru, ko v njem ni zadetkov za iskani niz.

\subsubsection{POMOČ UPORABNIKOM IN INTERAKCIJA Z NJIMI}

Uporabniki, ki bodo na portalu iskali pomoč za njegovo uporabo, bodo razočarani, saj je vsebin zelo malo in niso jasno izpostavljene na naslovni strani oziroma niso samo klik proč (nekaj nasvetov glede iskanj in pojasnil o vsebini portala najdemo na strani O Franu med pogostimi vprašanji). Na portalu tudi nikjer ni ponujena informacija o tem, da obstajajo predstavitveni posnetki s primeri uporabe, ki jih najdemo na Franovem kanalu na Vimeu (http://vimeo.com/user33363446/videos) in tudi na Predstavitvenem portalu spletnih 
jezikovnih virov za slovenščino (http://viri.trojina.si).

Uporabniki se sicer po pomoč pri konkretnih zagatah lahko zatečejo tudi k jezikovni ali terminološki svetovalnici, ki je ponujena v oknu s filtri. Nekoliko nadležno je sicer, da klik na »Oddajte vprašanje« uporabnika najprej popelje do svetovalnice, kjer mora izbrati povezavo »Zastavi novo jezikovno/terminološko vprašanje«, da se mu odpre okno za vnos.

Drugačen način interakcije uporabnikom omogoča aktivno sodelovanje pri oblikovanju slovarskih vsebin, saj lahko predlagajo ustreznejše slovenske besede namesto tujih ali pa glasujejo za predloge. Izkaže se, da gre bolj za promocijske namene, saj uporabniki lahko sodelujejo le pri besedah z gumbom »Glasuj«, teh pa je trenutno v SNB nekaj manj kot 90, v Sprotnem slovarju slovenskega jezika pa samo pet. Presenetljivo je, da je možnost interakcije ponujena pri nekaterih iztočnicah v SNB, ki so že uslovarjene v SSKJ2 (npr. bodibilding in pirsing) in tako z vidika avtorjev že sprejete kot del knjižne slovenščine. Poleg tega portal uporabnikom ne ponuja možnosti, da bi si ogledali vse besede, pri katerih je mogoče dati predlog ali glasovati o drugih predlogih.

\subsubsection{PRILAGOJENOST ZA MOBILNE NAPRAVE}

Eden od pomembnih delov uporabniške prijaznosti spletnih jezikovnih virov je tudi njihova prilagojenost za uporabo na mobilnih napravah. ${ }^{31} \mathrm{Na}$ tabličnem računalniku je delovanje Frana skoraj identično delovanju na računalniku, saj je zaslon podobne velikosti. Na mobilnem telefonu, ki ima zaslon precej manjši, se spletna stran prilagodi zaslonu tako, da se okno z zadetki prilagodi širini zaslona, okno s filtri pa je na voljo s klikom na gumb v desnem zgornjem kotu (Slika 9). A to je tudi vse, kar je bilo za mobilne telefone narejeno - zaradi ožjega zaslona so strani z zadetki še daljše, kar zahteva še več premikanja po strani

${ }^{31}$ Delovanje portala smo preizkusili na tabličnem računalniku iPad in pametnem telefonu iPhone $4 \mathrm{~S}$. 
navzdol.

Označevanje in pojasnjevanje delov zgradbe slovarja in slovarskih kratic postane na mobilnih napravah z zaslonom na dotik moteče, saj se ne sklada $\mathrm{s}$ primarnim namenom dotikanja zaslona, tj. premikanjem gor in dol po strani ali povečevanjem/pomanjševanjem besedila na njej. Ob takšnem številu slovarjev se zdi ustreznejša rešitev aplikacija (kar je ustaljena praksa pri podobnih tujih in domačih portalih), v kateri uporabnik lahko prilagodi nastavitve (npr. izbere slovarje) v skladu s svojimi preferencami.

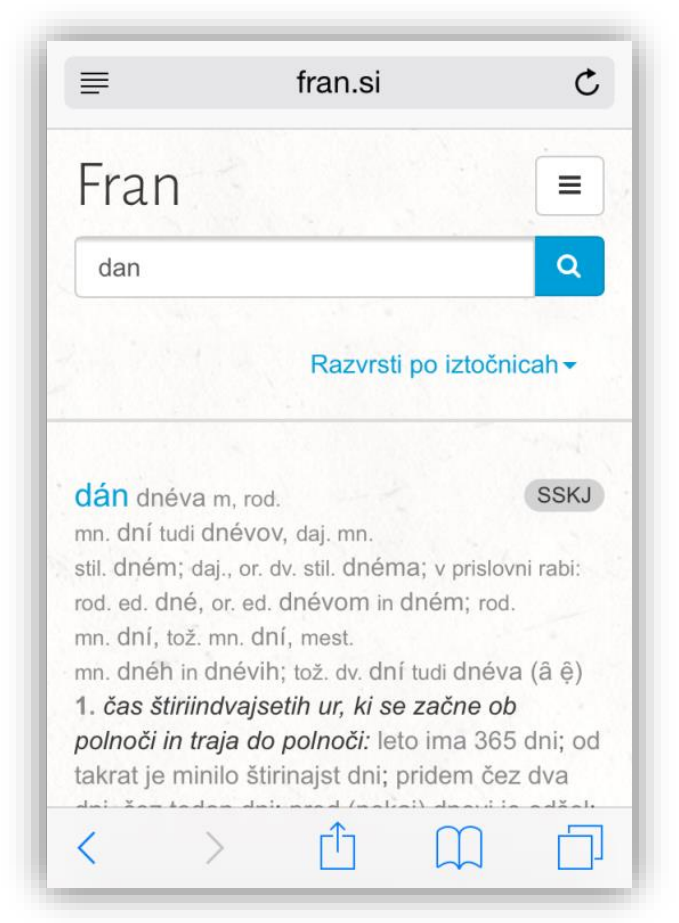

Slika 9: Fran na mobilnem telefonu iPhone 4S.

\section{ZAKLJUČEK}

Portal Fran je dobrodošla novost v slovenskem slovarskem prostoru, ki bo imel, upoštevajoč število obiskov ( $\mathrm{v}$ času pisanja prispevka oz. $\mathrm{v}$ dveh mesecih in pol 
po začetku delovanja je imel že skoraj 310.000 iskanj oz. skoraj 3.80o iskanj na dan),32 velik vpliv na rabo slovarjev pri nas, zlasti $\mathrm{z}$ vidika privajanja uporabnikov na iskanje v enojezičnih slovarjih po več virih hkrati, saj so bili do zdaj vajeni iskati informacije po vsakem viru posebej. Veliko število uporabnikov je tudi odlična priložnost za raziskave o rabi portala in njegovih uporabnikih, kar portal nujno potrebuje. Ena glavnih pomanjkljivosti portala Fran je namreč ta, da daje vtis, kot da se ne želi opredeliti o svojem ciljnem uporabniku in raje skuša ugajati (zelo) različnim profilom uporabnikov. Posledično portal nima jasne hierarhije virov, tj. nima osrednjega slovarja ali osrednje skupine slovarjev. Razvrščanje zadetkov daje sicer prednost zadetkom iz splošnih slovarjev, pri čemer kriterij razvrščanja zadetkov znotraj splošnih slovarjev ni smiseln, vendar pa se zadetkov pri enostavnem iskanju ne da omejiti na vse splošne slovarje, ampak zgolj na posamične. Tako uporabnikom splošnih slovarjev, za katere bi pričakovali, da jih bo med obiskovalci portala največ, zaradi vsiljenih zadetkov iz zgodovinskih, terminoloških in ostalih virov preti preobremenitev z informacijami, pred katero svari Tarp (2009). Deloma zadovoljivo je poskrbljeno tudi za potrebe uporabnikov terminoloških slovarjev in Slovenskega lingvističnega atlasa, ki jih portal pošilja na druge strani ali navaja podatke $\mathrm{v}$ ločenih oknih. Zdi se, da je še najbolje zadoščeno uporabnikom zgodovinskih slovarjev: pri razvrščanju so zadetki iz zgodovinskih slovarjev na drugem mestu, filtri pa omogočajo omejevanje zadetkov samo na omenjeno skupino slovarjev ali na posamezni slovar.

Čeprav portal ponuja nekaj funkcionalnosti, ki izkoriščajo prednosti elektronskega medija in naj bi bile v pomoč uporabnikom, pa je teh odločno premalo. Obenem so tudi nekatere obstoječe funkcionalnosti za uporabnika lahko bolj nadležne kot koristne, npr. povezave na vse zadetke po abecednem vrstnem redu pri približkih neuspešnih iskanj in (pretirano) razlaganje zgradbe slovarskih sestavkov. Način podajanja slovarskih informacij v med spletnimi

32 Podatek je bil pridobljen na strani http://www.fran.si/o-portalu. 
uporabniki ne preveč priljubljenem linearnem oz. tiskanem prikazu med drugim odraža širši problem, namreč da portal vključuje slovarske vsebine, ki so (bile) izdelane v prvi vrsti za tiskani medij, kar velja tudi za najnovejše slovarske vire, kot sta SSKJ2 in SNB. Ker portal Fran prevzema vlogo dostopne točke do slovarjev ISJFR (v portal naj bi se dodajali tudi bodoči slovarji, izdelani na ISJFR), se postavlja vprašanje, ali bo zasnova portala Fran diktirala tudi zasnovo bodočih slovarjev in leksikografije na ISJFR.

\section{LITERATURA}

Dziemianko, A. (2015): Colours in Online Dictionaries: A Case of Functional Labels. International Journal of Lexicography, 28 (1): 27-61.

Lew, R. (2011): Online dictionaries of English. V P. A. Fuertes-Olivera in H. Bergenholtz (ur.): e-Lexicography: The Internet, Digital Initiatives and Lexicography: 230-250. London: Continuum.

Lew, R. in Mitton, R. (2011): Not the Word I Wanted? How Online English Learners' Dictionaries Deal with Misspelled Words. V I. Kosem in K. Kosem (ur.): Electronic Lexicography in the 21st Century: New Applications for New Users. Proceedings of eLex 2011, Bled, 10-12 November 2011. 165-174. Trojina: zavod za uporabno slovenistiko.

Kosem, I., Stritar, M., Može, S., Zwitter Vitez, A., Arhar Holdt, Š. in Rozman, T. (2012): Analiza jezikovnih težav učencev: korpusni pristop. Trojina: zavod za uporabno slovenistiko.

Müller-Spitzer, C., Koplenig, A., Töpel in A. (2012): Online dictionary use: Key findings from an empirical research project:. V: S. Granger in M. Paquot (ur.): Electronic Lexicography: 425-458. Oxford: Oxford University Press.

Resolucija o nacionalnem programu za jezikovno politiko (2014-2018). Dostopno na: 
Resolucija_-_sprejeto_besedilo__15.7.2013_.pdf (28. 12. 2014).

Romih, M. in Krek, S. (2012): Termania - prosto dostopni spletni slovarski portal. V T. Erjavec in J. Žganec Gros (ur.): Zbornik Osme konference Jezikoune tehnologije, 8. do 12. oktober 2012, Ljubljana, Slovenia: zbornik 15. mednarodne multikonference Informacijska družba - IS 2012, zvezek C: 163-166. Ljubljana: Institut Jožef Stefan.

Rozman, T. (2010): Vloga enojezičnega razlagalnega slovarja slovenščine pri razvoju jezikovne zmožnosti. Doktorska disertacija. Ljubljana: Filozofska fakulteta.

Tarp, S. (2009): Beyond Lexicography: New Visions and Challenges in the Information Age. V H. Bergenholtz, S. Nielsen in S. Tarp (ur.): Lexicography at a Crossroads: Dictionaries and Encyclopedias Today, Lexicographical Tools Tomorrow: 17-32. Bern: Peter Lang.

\section{Spletne strani:}

Collins dictionaries. Dostopno prek: http://www.collinsdictionary.com (28. 12. 2014).

Dictionary.com. Dostopno prek: http://dictionary.reference.com (28. 12. 2014).

DWDS. Dostopno prek: http://www.dwds.de (28. 12. 2014).

e-slovarji DZS. Dostopno prek: http://slovarji.dzs.si/ (29. 12. 2014).

Euroterm. Dostopno prek: http://www.evroterm.gov.si/ (29. 12. 2014).

Fran. Dostopno prek: http://www.fran.si (28. 12.-31. 12. 2014).

K Dictionaries. Dostopno prek: http://kdictionaries-online.com (28. 12. 2014).

Leo. Dostopno prek: https://dict.leo.org (28. 12. 2014).

Macmillan English Dictionary. Dostopno prek:

http://www.macmillandictionary.com (28. 12. 2014). 
Merriam-Webster dictionary. Dostopno prek: http://www.merriam-webster.com (28. 12. 2014).

Oxford Dictionaries. Dostopno prek: http://www.oxforddictionaries.com (28. 12. 2014).

Onelook. Dostopno prek: http://www.onelook.com (29. 12. 2014).

Pons (slovenska stran). Dostopno prek: http://sl.pons.com (29. 12. 2014).

Predstavitveni portal spletnih jezikovnih virov za slovenščino. Dostopno prek: http://viri.trojina.si (29. 12. 2014).

Spletni slovarji. Dostopno prek: http://www.evroterm.gov.si/slovar/ (29. 12. 2014).

SSKJ2: Slovar slovenskega knjižnega jezika: druga, dopolnjena in deloma prenovljena izdaja (2014). Dostopno na: http://www.sskj2.si (29. 12. 2014).

Šolar. Dostopno prek: http://www.korpus-solar.net/ (31. 12. 2014).

Termania. Dostopno prek: http://www.termania.net (29. 12. 2014).

Terminologišče. Dostopno prek: http://isjfr.zrc-sazu.si/sl/terminologisce/slovarji (29. 12. 2014).

Vimeo - kanal portala Fran. Dostopno prek: http://vimeo.com/user33363446/videos (30. 12. 2014).

Vzporedni iskalnik po Slovenskem pravopisu, SSKJ, Novi Besedi in Gigafidi. Dostopno prek: http://m.anyterm.info/praslon.php (29. 12. 2014).

Wordnik. Dostopno prek: http://www.wordnik.com (28. 12. 2014).

WordReference. Dostopno prek: http://www.wordreference.com (28. 12. 2014). 


\section{FRAN: INTELLIGENT AND INTUITIVE?}

Dictionaries are often (also) offered to users through dictionary portals which combine different dictionaries and often other reference works. Such portals are the answer to the needs of a modern dictionary user, used to a instantaneous access to different types of information at a single site. Dictionary portals have been present in Slovenia for some time, however, the recently launched portal Fran of the Fran Ramovš Institute of the Slovenian language at the Research Centre of the Slovenian Academy of Sciences and Arts (ZRC SAZU) is the first one to focus solely on monolingual dictionaries (general, historic, dialectal and terminological) and thus brings an important change to the use of monolingual dictionaries in Slovenia. The paper first looks at the classification of multi-dictionary websites and offers an overview of selected foreign and Slovene dictionary portals. Then, a detailed presentation of Fran is made and an evaluation undertaken. While Fran appears useful by offering access to 21 different dictionaries, especially all Slovene general dictionaries (although the access to the recently published second edition of the Dictionary of Literary Slovene is limited to the users who purchased the print version), a closer inspection reveals several problematic aspects, such as a lack of a central dictionary or a group of dictionaries, unclear criteria for ordering of results, using print view for showing results, limited filter functionality (e.g. no option of limiting the results to contemporary general dictionaries), and links to external websites instead of full entries for terminological dictionaries. In general, it appears that the limitations of the design and functionality of Fran reflect the fact that most of the dictionaries it contains have been developed for the printed medium. This begs a question whether this is a direction that is advocated by the authors/owners of Fran, a direction that will be taken by all the dictionaries that will be added to the portal in the future, as well as the lexicography at the Fran Ramovš Institute of the Slovenian language.

Ključne besede: dictionary portal, dictionaries, lexicography, user-friendliness, interface 
To delo je ponujeno pod licenco Creative Commons: Priznanje avtorstvaDeljenje pod enakimi pogoji 2.5 Slovenija.

This work is licensed under the Creative Commons Attribution ShareAlike 2.5 License Slovenia.

http://creativecommons.org/licenses/by-sa/2.5/si/

(c) (1) () () 